\title{
Analytical Methods in Photoelectrochemical Treatment of Phenol
}

\author{
Paulo R. M. Lopes, Renato N. Montagnolli and Ederio D. Bidoia* \\ Departamento de Bioquímica e Microbiologia, Instituto de Biociências, \\ Universidade Estadual Paulista, Rio Claro-SP, Brazil
}

\begin{abstract}
O presente estudo visou o tratamento de efluente simulado, contendo fenol por processos fotocatalítico e fotolítico com análise toxicológica das soluções fenólicas. Dois sistemas de tratamento foram propostos com radiação UV, eletrodos maciços e potencial elétrico. No primeiro sistema (S1), a concentração de fenol foi determinada por espectrofotometria direta em $269 \mathrm{~nm}$ e o segundo (S2) por meio do método fotométrico direto (4-aminoantipirina). Testes de toxicidade foram realizados com dois microrganismos: Escherichia coli e Saccharomyces cerevisiae. Os resultados de S1 demonstraram que conclusões errôneas podem ser retiradas em relação ao aumento de absorbância no pico do fenol de acordo com o tempo de tratamento. Contudo, o método fotométrico direto foi capaz de identificar a redução do fenol em S2 e observou-se que os tratamentos propostos degradaram as moléculas de fenol em solução. Também, no tratamento com fonte ultravioleta de alta energia (UVC), a degradação fenólica deve-se principalmente à fotólise.
\end{abstract}

The aim of the study was to propose a treatment of simulated wastewater containing phenol by photocatalytic and photolytic processes and analyze the toxicity of these phenolic solutions. Two treatment systems were performed with UV radiation, solid electrodes and electric potential. In the first system (S1) phenol concentration was determined by UV direct spectrophotometry $(269 \mathrm{~nm})$ and in the second (S2) by direct photometric method (4-aminoantipyrine). Toxicological tests were carried out using two microorganisms: Escherichia coli and Saccharomyces cerevisiae. S1 results showed that erroneous conclusions can be drawn by absorbance values increase at phenol peak. Nevertheless, direct photometric method was able to identify phenol reduction in S2 and the proposed treatments degraded phenol in solution. Also, in treatment using high energy ultraviolet radiation (UVC), the phenol degradation was mainly due to the photolytic process.

Keywords: phenol, photocatalysis, photolysis, $\mathrm{TiO}_{2}$, toxicity

\section{Introduction}

Industrial effluents are formed by a variety of substances such as organic and/or inorganic compounds, which can be highly dangerous when released improperly in environment. Among such wide range of pollutants, phenolic compounds have attracted attention due to their large number and diversity of species with a high deleterious potential in aquatic biota. ${ }^{1,2}$

Phenolic compounds contamination in drinking water is a serious public health problem. Their easy penetration into skin and cell membranes induces a food chain accumulation which leads to mutagenic and hepatotoxic effects, besides affecting reactions in photosynthesis and respiration processes. ${ }^{3}$

*e-mail: ederio@rc.unesp.br
According to USEPA ${ }^{4}$ phenolic compounds are persistent, bioaccumulative and potentially toxic when released in the environment. Furthermore, $\mathrm{Wu}$ and $\mathrm{Zhou}^{5}$ reported that even at low concentration these substances are toxic to biota. Hence proper treatment of phenolic effluents presents high importance in environmental protection.

The use of advanced technologies in catalytic oxidation has been consolidated during development of treatment systems for toxic and refractory compounds. Advanced oxidation processes (AOPs) are characterized by hydroxyl radicals $\left(\mathrm{OH}^{*}\right)$ generation, responsible for oxidizing organic compounds. ${ }^{6-8}$ Thus, heterogeneous photocatalysis appears as an effective organic molecules degradation alternative. This process is based on the ability of photocatalytic semiconductors such as titanium dioxide $\left(\mathrm{TiO}_{2}\right)$ when subjected them to UV radiation in produce hydroxyl radicals. ${ }^{6,7}$ 
When $\mathrm{TiO}_{2}$ particles are irradiated by wavelengths shorter than $390 \mathrm{~nm}(\mathrm{UV})$, an electron/hole pair $\left(\mathrm{e}^{-} / \mathrm{h}^{+}\right)$is formed, as demonstrated in Figure 1. Electrons are excited and move from valence band to conduction band. Thereby, valence band becomes positively charged owing to electron movement that creates a hole positively charged $\left(h^{+}\right)$. This hole is able to promote water or hydroxide ion oxidation in semiconductor surface leading to hydroxyl radicals formation (highly oxidants). Also, electrons can bind to oxygen resulting in a superoxide ion. ${ }^{9}$

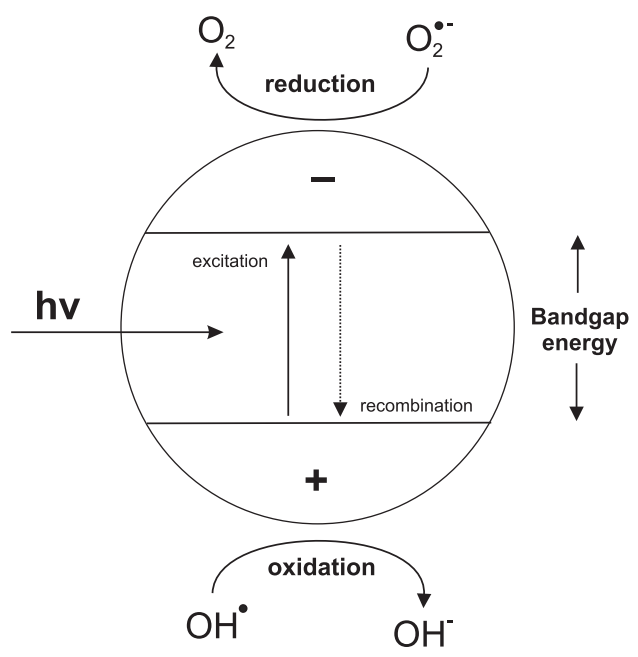

Figure 1. $\mathrm{e}^{-} / \mathrm{h}^{+}$pair formation in semiconductor surface under UV excitation in heterogeneous photocatalysis.

Still, the practical application of this technology has been limited due to some drawbacks mainly related to final separation of $\mathrm{TiO}_{2}$ particles in suspension, ${ }^{10}$ and the low quantum yield, which is usually less than $5 \% .{ }^{11}$ Moreover, in absence of electric field, most $\mathrm{e}^{-} / \mathrm{h}^{+}$pairs recombine (Figure 1), causing an over than $95 \%$ loss of light energy to heat. ${ }^{12}$

The application of a positive potential on the titanium electrode coated with $\mathrm{TiO}_{2}$ decreases its Fermi level $\left(\mathrm{E}_{\mathrm{F}}\right)$. Thus, photogenerated electrons $\left(\mathrm{e}^{-}\right)$are carried to the counter electrode and the holes $\left(\mathrm{h}^{+}\right)$remain on the $\mathrm{TiO}_{2}$ surface due to the electronic drainage by the current. Therefore, applying an electric potential reduces the $\mathrm{e}^{-} / \mathrm{h}^{+}$pairs recombination. According to this, the formation $\mathrm{OH}^{\cdot}$ radical increases when $\mathrm{TiO}_{2}$ is irradiated by $\mathrm{UV}^{13}$ and provides a higher efficiency in treatment process. ${ }^{14}$

It was demonstrated that phenolic wastes treated by AOPs undergo a partial degradation of molecule by opening aromatic ring into organic acids that are nutrients for microorganisms. Thereby, phenol partial degradation provides a low cost pretreatment for biological process. ${ }^{5}$

This study examined a phenol solution degradation by photolytic and photocatalytic methods evaluating the effect of different operational parameters, such as solid electrodes coated with semiconductor oxides and electric potential. Both electric potential and ultraviolet lamp were with low power aiming to a low cost photocatalysis treatment.

Treatments were performed by using UVC and following electrodes: thermal $\left(\mathrm{TiO}_{2}\right)$, commercial (CE) and plastic (PE), in absence or in presence of electric potential (e). Furthermore, toxic potential of samples treated was investigated using two microorganisms as test organisms.

\section{Experimental}

\section{Phenol solution}

Phenol solution was prepared by diluting $0.100 \mathrm{~g}$ of phenol PA in $1.000 \mathrm{~L}$ of Milli-Q water (Millipore ${ }^{\circledR}$ ) that established an initial concentration (conc. phenol ${ }_{0}$ ) of $0.100 \mathrm{~g} \mathrm{~L}^{-1}$. It was added $2.000 \mathrm{~g}$ of sodium sulfate as supporting electrolyte $\left(2.000 \mathrm{~g} \mathrm{~L}^{-1} \mathrm{Na}_{2} \mathrm{SO}_{4}\right)$.

\section{Electrodes}

Different electrodes were analyzed with same dimension: $0.050 \mathrm{~m}$ high, $0.050 \mathrm{~m}$ wide and $0.001 \mathrm{~m}$ thick.

Titanium electrode coated with titanium dioxide $\left(\mathrm{TiO}_{2}\right)$

Titanium electrode coated with a thin titanium dioxide $\left(\mathrm{TiO}_{2}\right)$ film was formed after thermal treatment by a metal plate base (Ti) and $\mathrm{TiO}_{2}$ film. It was used due to its photocatalytic ability when irradiated by a UV source.

The electrodes were sanded and washed with Milli-Q water and acetone before thermal treatment. Afterwards, Ti plate remained in preheated muffle furnace for $10 \mathrm{~min}$ at $750{ }^{\circ} \mathrm{C}$ in air presence to the thermal titanium dioxide film formation. ${ }^{15}$ The thermal $\mathrm{TiO}_{2}$ film prepared was about $2.50 \mu \mathrm{m}$ thick. ${ }^{16,17}$

\section{Commercial electrode (CE)}

Commercial electrode (CE) supplied by De Nora ${ }^{17}$ was composed by titanium base plate coated with titanium and ruthenium oxides $\left(\mathrm{Ti} / 70 \% \mathrm{TiO}_{2}-30 \% \mathrm{RuO}_{2}\right)$.

This electrode has a high efficiency in organic compounds degradation by electrolysis in electrolytic treatments. ${ }^{8,19,20}$ However, it had not yet been studied for the proposed system.

\section{Plastic electrode coated with aluminum foil (PE)}

Plastic electrode coated with aluminum foil (PE) was studied as a control experiment with no effect of electrode in phenol concentration. 


\section{Characterization of the electrodes}

The thermal electrode prepared was analyzed using $\mathrm{X}$-ray diffraction spectrometry. This technique was used to identify and characterize the formation of films of pure titanium dioxide $\left(\mathrm{TiO}_{2}\right)$.

The characterization was performed using a SIEMENS ${ }^{\circledR}$ D5000-kristalloflex model X-ray diffraction spectrometer, coupled to a texture goniometer and $40 \mathrm{kV}, 30 \mathrm{~mA}$ copper tube.

\section{Ultraviolet radiation}

The UV radiation used in treatment system was originated from a germicidal lamp Starlux ${ }^{\circledast} 15 \mathrm{~W}$ with emission spectrum in UVC range (100-290 nm). The use of lower wattage and more economical lamp becomes a viable option in photocatalytic oxidation treatment.

Figure 2 shows the UVC lamp emission spectrum, in which there are no defined emission bands. On the other hand, it can be observed emission peaks with a high intensity $\left(\lambda_{\max }\right)$ in $250 \mathrm{~nm}$.

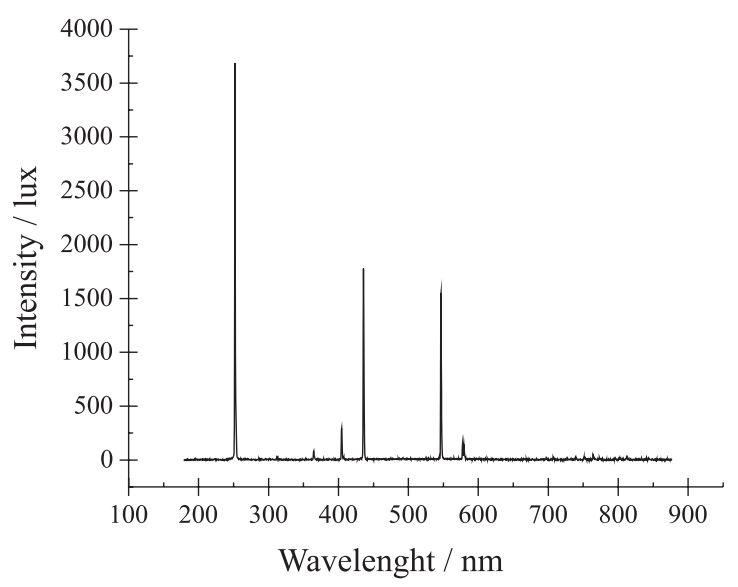

Figure 2. Emission spectrum of UV lamp $15 \mathrm{~W}$.

\section{Determination of phenol concentration}

Phenol quantification was performed by UV direct spectrophotometry and direct photometric method. Both methodologies used spectrophotometer Shimadzu ${ }^{\circledR}$ - Model 2401 PC.

\section{UV direct spectrophotometry (method 1)}

First method analyzed $269 \mathrm{~nm}$ absorbance. This wavelength refers to the phenol absorbance peak and thus the more concentrated sample the greater the absorbance. ${ }^{21}$

Initially, standard samples with known phenol concentrations were prepared to obtain the following equation: $\mathrm{Abs}_{269}=(0.01582 \times[$ phenol $])-0.00189$; $\mathrm{R}=0.9999$.

\section{Direct photometric method (method 2)}

Method 2 was based on method D 5530 - Standard Methods for the Examination of Water and Wastewater, ${ }^{22}$ also used by Lathasree et al. ${ }^{23}$ Phenolic compounds reacts with 4-aminoantipyrine at $\mathrm{pH} 7.9 \pm 0.1$ forming a brownishorange compound. Subsequently sample absorbance was measured at $500 \mathrm{~nm}$.

Similar to method 1 an equation involving phenol concentration and absorbance values was determined: Abs $=(0.005315 \times[$ phenol $])+0.00337 ; R=0.9998$.

\section{Treatment system}

Treatment system components were: glass cell, UV lamp, working electrode, counter electrode, electric potential and magnetic stirrer (Figure 3).

The counter electrode corresponds to a $0.085 \mathrm{~m}$ diameter nickel mesh $(\mathrm{Ni})$ only used when the potential was applied to $\mathrm{TiO}_{2}$ electrode. The counter electrode was connected to negative pole in electric potential (cathode) and $\mathrm{TiO}_{2}$ to positive pole (anode).

The electric potential (e) used in treatment system was only a $1.500 \mathrm{~V}$ power supply $-200 \mathrm{~mA}$ and its utilization produces an electronic drainage in the anode. Moreover, it was used a UV lamp with emission spectrum in UVC range.

Phenol degradation was carried out in a batch reactor containing $0.240 \mathrm{~L}$ of phenol solution. UVC lamp was located above glass cell of $0.250 \mathrm{~L}$ and the electrodes were into phenol solution.

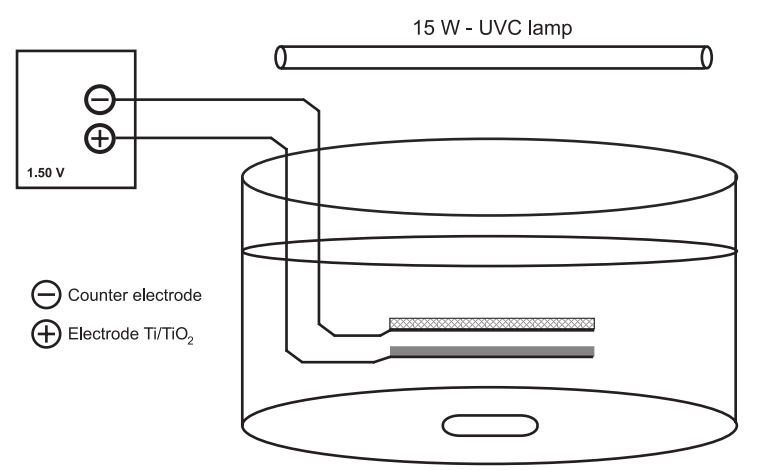

Figure 3. Scheme of treatment system.

\section{Assays composition}

Two treatments were carried out with distinct methods of phenol concentration quantification.

First treatment (T1) examined phenol degradation for $23 \mathrm{~h}$ by method 1 in three assays: lamp (UVC only), 
lamp-electrode $\left(\mathrm{UVC}+\mathrm{TiO}_{2}\right)$ and lamp-electrode-electric potential $\left(\mathrm{UVC}+\mathrm{TiO}_{2}+\mathrm{e}\right)$. The sample measurements were done in $\mathrm{t} 0, \mathrm{t} 5$ and $\mathrm{t} 23 \mathrm{~h}$ and analyzed in duplicates.

$\mathrm{T} 2$ was composed by UV radiation and three different working electrodes. The treatment was performed for $6 \mathrm{~h}$ and the determination of phenol concentration in solution used method 2. Thus, four assays were prepared: plastic electrode (UVC/PE), commercial electrode (UVC/CE), titanium electrode $\left(\mathrm{UVC} / \mathrm{TiO}_{2}\right)$ and titanium electrode coupled to electric potential $\left(\mathrm{UVC} / \mathrm{TiO}_{2}+\mathrm{e}\right)$. The sample measurements were done in $\mathrm{t} 0, \mathrm{t} 1, \mathrm{t} 2, \mathrm{t} 3, \mathrm{t} 4, \mathrm{t} 5$ and $\mathrm{t} 6 \mathrm{~h}$ and analyzed in duplicates.

\section{Toxicity tests}

Toxicity tests used two different test organisms: Gram-negative eubacteria (Escherichia coli) and yeast (Saccharomyces cerevisiae). These different groups were chosen for toxicological analysis of phenol solutions based on their difference in cell envelope structure.

The first toxicological test used Escherichia coli (ATCC 8739). Inhibition percentage that indicates cellular toxicity was determined using ToxTrack Toxicity Test Kit (Hach Company ${ }^{\circledR}$ ) and spectrophotometer Odyssey $\mathrm{Hach}^{\circledR}$ model DR/2500 (Method 10017). The method is based on reduction of a redox indicator dye (resazurin) by bacterial respiration. Thus, color variations were measured at $603 \mathrm{~nm}$ absorbance and inhibition percentage was determined for the samples.

Furthermore, toxicological test with Saccharomyces cerevisiae were made according to Régis and Bidoia ${ }^{24}$ and Inazaki et al. ${ }^{25} \mathrm{~S}$. cerevisiae cell suspension was exposed to phenolic samples. Test tubes were incubated at $28{ }^{\circ} \mathrm{C}$ for seven days. Cells were counted in a Neubauer chamber with erythrosine. Living cells remained translucent (no color) and dead cells stained in red under the microscope. ${ }^{26}$ Results were expressed on cell viability ([living cells/total cells] $\times 100$ ).

\section{Results and Discussion}

\section{$X$-ray diffraction}

It was analyzed with $\mathrm{X}$-ray diffraction the titanium electrode covered with a thin layer of $\mathrm{TiO}_{2}$ to characterize and identify the crystalline structures present. The examined electrodes were: Ti plate (Figure 4a) and $\mathrm{TiO}_{2}$ (Figure 4b).

The diffraction patterns interpreted by the software Diffrac-At Siemens ${ }^{\circledR}$ revealed that the thermally produced semiconductor $\mathrm{TiO}_{2}$ film is found in rutile form (Figure 4). The anatase and brookite forms were not identified in the electrodes used in the photocatalytic treatment.
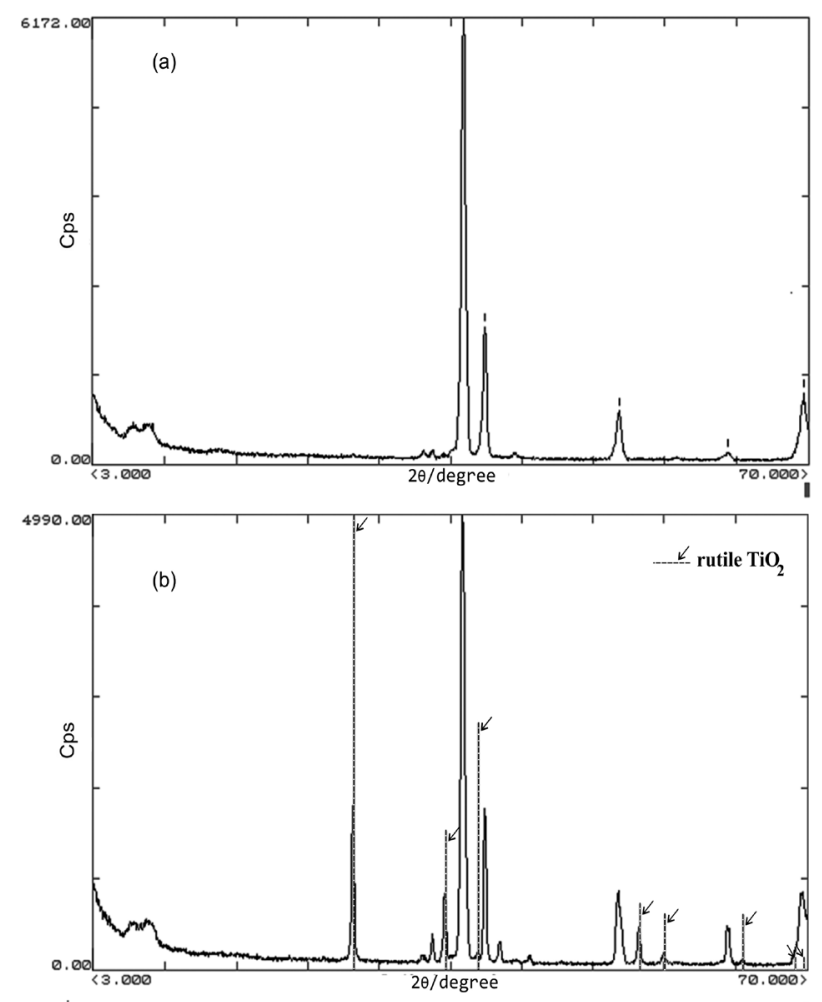

Figure 4. X-ray diffraction patterns of the electrodes used. (a) Ti plate; (b) $\mathrm{TiO}_{2}$.

The same results were found when the thermal electrode was prepared at $700^{\circ} \mathrm{C}$ for $10 \mathrm{~min} \cdot{ }^{13,15,27}$ Similarly, Castañeda et al. ${ }^{28}$ reported that the rutile phase is formed at high temperatures and the anatase phase is formed at lower temperatures (about $450^{\circ} \mathrm{C}$ ).

\section{Treatment 1}

It was evaluated in treatment 1 (T1) UVC effect in phenol solution in presence or absence of $\mathrm{TiO}_{2}$ electrode and electric potential. Results were determined by method 1 in initial time (t0), after 5 and $23 \mathrm{~h}$ treatment (Figure 5).

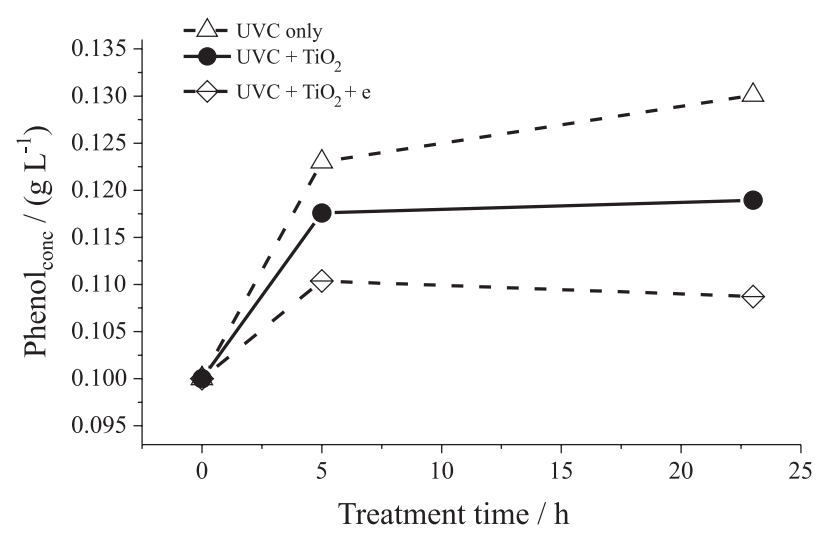

Figure 5. Phenol concentration in treatment 1 (method 1$)$. 
According to Figure 5, absorbance values of samples treated by photolysis (UVC only) increased with time. Therefore, erroneous conclusions can be drawn regarding phenol concentration because such phenol increase is not feasible. There was no change in operational parameters and solution composition after experiment beginning.

An absorbance increase at $269 \mathrm{~nm}$ in all assays irradiated by UVC (Method 1) can be observed in Figure 6 . The higher values observed were due to a color change in phenol solution, which was colorless at the beginning (t0) and became orange after UVC radiation. Phenol degradation by UVC photolysis formed byproducts in solution and some of these compounds interfered in results due to the increase of absorbance in $269 \mathrm{~nm}$.

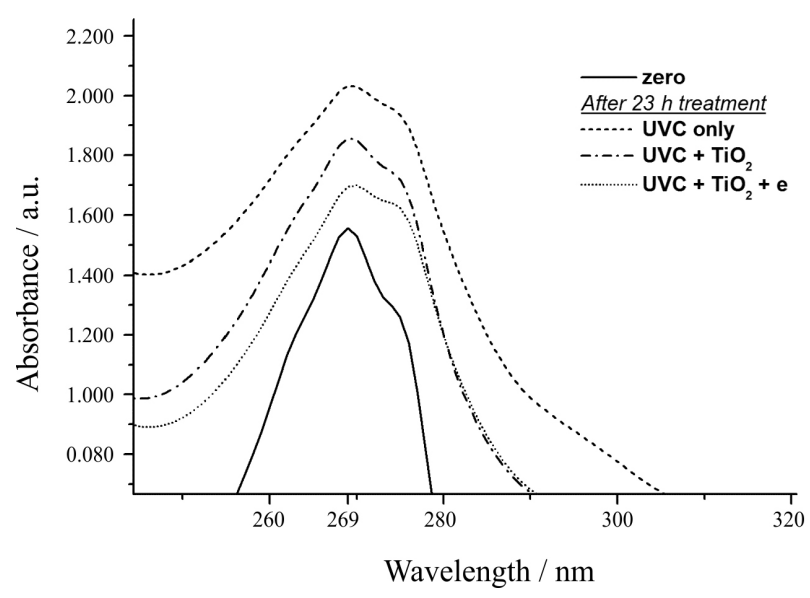

Figure 6. Absorbance spectra in treatment $1(\operatorname{method} 1)$.

\section{Treatment 2}

The second treatment (T2) determined the effect of different electrodes under UVC radiation, but in this case phenol concentration was quantified by method 2 (Figure 7).

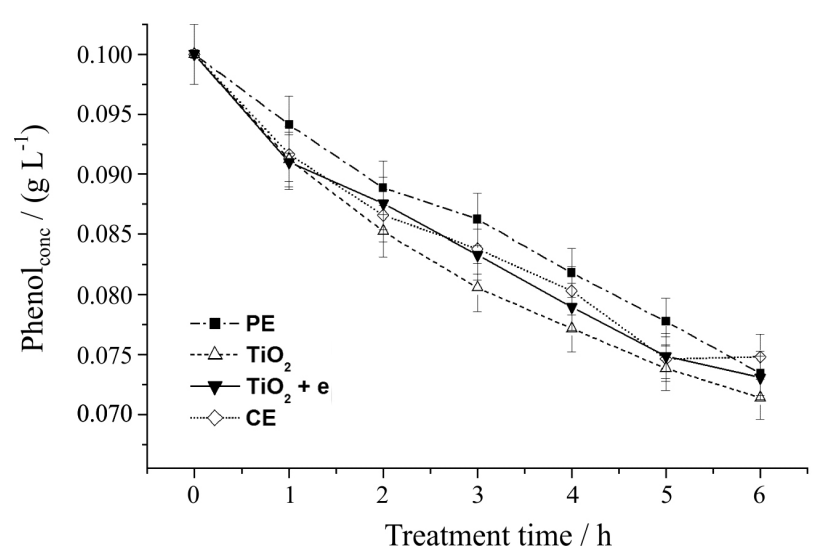

Figure 7. Phenol concentration in treatment $2(\operatorname{method} 2)$.
Figure 7 demonstrates absorbance decrease in function of time in all assays, i.e., phenol concentration reduction in relation to treatment time. Thus, Method 2 was able to quantify the real phenol concentration in solution unlike method 1 (Figure 5).

In T2 phenol reduction was about $30.0-35.0 \%$, as shown in Figure 7. All four assays presented similar values of concentration after $6 \mathrm{~h}$ treatment ranging from: $0.07129 \mathrm{~g} \mathrm{~L}^{-1}\left(\mathrm{UVC}_{\mathrm{TiO}}\right)$ and $0.07481 \mathrm{~g} \mathrm{~L}^{-1}$ (UVC/CE).

\section{Toxicity}

Results of toxicological tests showed that all samples were toxic neither to bacteria (E. coli), nor for yeast (S. cerevisiae).

Tests conducted with ToxTrack Toxicity Test Kit (Hach Company ${ }^{\circledR}$ ) and Escherichia coli presented pink color and absorbance similar to control assay, pointing that no inhibition in bacterial metabolism was promoted by phenol in solution. The inhibition percentage of $0 \%$ was obtained in accordance with ToxTrack ${ }^{\circledR}$ method.

Besides, phenol solutions treated in $\mathrm{T} 1$ and $\mathrm{T} 2 \mathrm{did}$ not present toxicity to Saccharomyces cerevisiae cells. Regarding toxicological tests on yeast cell viability, S. cerevisiae cells were not stained by erythrosine even after a week of exposure to phenol samples. Their translucent appearance under microscope indicated that cells remained alive. The results observed in control assay (S. cerevisiae cells and water) were similar to phenol samples assays. In all toxicological assays yeast living cells were presented above $95 \%$.

\section{Discussion}

Phenol degradation begins when the aromatic ring is hydroxylated to produce intermediate compounds as hydroquinone and/or catechol followed by the formation of $p$-benzoquinone and/or $o$-benzoquinone. Finally, opened ring originates organic acids. ${ }^{29}$

Among these compounds some may possess chromophores groups. These organic molecules in samples presented absorbance values in visible spectrum and also increased UV absorbance. Consequently, higher absorbance values were found at $269 \mathrm{~nm}$ phenol peak, as shown in T1 (Figures 4 and 5). Within these compounds, catechol and hydroquinone are highlighted. ${ }^{30}$

In photocatalysis, byproducts are formed and some has chromophore groups can absorb UV radiation in a wavelength near phenol peak $269 \mathrm{~nm} .{ }^{30}$ Thus, absorbance curves may be added and promoted higher values at $269 \mathrm{~nm}$ absorbance. Therefore, the UV direct spectrophotometry 
(method 1) was not able to determine the phenol concentration in this case. Moreover, method 2 became the most suitable because it eliminated the influence of various byproducts formed from the phenol degradation in UV absorbance.

Chun et al. ${ }^{31}$ observed that phenol solution is colorless and under UVC this solution gradually acquired an orange color in $\mathrm{TiO}_{2}$ and $\mathrm{O}_{2}$ absence, accordingly to results obtained. Phenol molecules suffered excitation by high energy radiation and reacted hence forming a polymeric residue in suspension which colored to the aqueous solution.

Moreover Johnson et al..$^{32}$ demonstrated that phenol was degraded into intermediate compounds (benzoquinone and carboxylic acids) during the photoelectrochemical degradation. They observed that the solution color changed to light brown with benzoquinone generation and returned to its original colorless appearance with the gradual conversion of this substance into carboxylic acids.

Under high energy radiation, such as UVC, the phenol solution assumed a brownish-orange color that reflected the absorbance increase of samples at $269 \mathrm{~nm}$. Thereafter, method 1 was unable to determine phenol concentration and method 2 could only be used in this case since there is formation of an orange compound with $500 \mathrm{~nm}$ wavelength absorbance.

There was a decrease in phenol concentration using 4-aminoantipyrine reaction methodology. It demonstrated that method 2 was able to quantify phenol reduction due to the treatment (Figure 7), unlike the analysis presented by method 1 (Figure 5).

In Figure 7 it was observed that phenol degradation is not dependent of the electrode and of electric potential application. Gimeno et al..$^{33}$ corroborated saying that phenols were degraded mainly by photolytic action when solution was under small wavelengths radiation at $254 \mathrm{~nm}$ (UVC spectrum).

The toxicological tests did not establish the inhibition percentage for the microorganisms used when exposed to phenol solutions. This is because in both cases there was no death or cellular inhibition. Results contradict some studies mentioning the biocidal character of phenol. ${ }^{34}$ Also Tiburtius et al. ${ }^{35}$ said that phenol concentrations above $0.070 \mathrm{~g} \mathrm{~L}^{-1}$ were considered toxic to some microbial populations. Thus, it was conclude that methods employed in this study were not able to evaluate the phenol toxicity for E. coli and S. cerevisiae cells.

\section{Conclusions}

The present study showed that treatment of phenol solutions in systems consisted by UVC radiation and different electrodes with or without application of electric potential was effective. However, concentration reduction was not detected by UV direct spectrophotometry $(269 \mathrm{~nm})$ due to formation of intermediate compounds. Their molecules present some chromophore groups that provide coloration to solution and, therefore, the direct photometric method was indicated. Moreover, it was determined that in treatment with high energy radiation (UVC) phenol degradation was only owing to photolysis.

\section{Acknowledgments}

CAPES, CNPq, FUNDUNESP, FAPESP and PRH-05 (UNESP/Rio Claro) are gratefully acknowledged.

\section{References}

1. Houk, V. S.; Mutat. Res. 1992, 227, 91.

2. Baird, C.; Química Ambiental, $2^{\text {nd }}$ ed.; Bookman: Porto Alegre, RS, Brasil, 2002.

3. Lewis, T. E.; Wolfinberg, T. F.; Barta, M. L.; Environ. Int. 2004, $30,1119$.

4. USEPA - United States Enviromental Protection Agency; Release and Pollution Prevention Report; Washington DC, 2000. <http://www.epa.gov/ttnatw01/hlthef/phenol.html>.

5. Wu, Z.; Zhou, M.; Environ. Sci. Technol. 2001, 35, 2698.

6. Litter, M. I.; Appl. Catal., B 1999, 23, 89.

7. Munter, R.; Proc. Est. Acad. Sci., Chem. 2001, 50, 59.

8. Inazaki, T. H.; de Moraes, P. B.; Régis, G.; Lopes, P. R. M.; Montagnolli, R. N.; Pião, A. C. S.; Bidoia, E. D.; J. Waste Water Treatment Analysis 2010, 1:101, doi:10.4172/21577587.1000101.

9. Butterfield, I. M.; Christensen, P. A.; Hamnett, A.; Shaw, K. E.; Walker, G. M.; Walker, S. A.; J. Appl. Electrochem. 1997, 27, 385.

10. Quan, X.; Chen, S.; Su, J.; Chen, J.; Chen, G.; Sep. Purif. Technol. 2004, 34, 73.

11. Li, X. Z.; Li, F. B.; Fan, C. M.; Sun, Y. P.; Water Res. 2002, 36, 2215.

12. Gerischer, H.; Electrochim. Acta 1993, 38, 3.

13. Harper, J. C.; Christensen, P. A.; Egerton, T. A.; Curtis, T. P.; Gunlazuardi, J.; J. Appl. Electrochem. 2001, 31, 623.

14. Walker, S. A.; Christensen, P. A.; Shaw, K. E.; Walker, G. M.; J. Electroanal. Chem. 1995, 393, 137.

15. Christensen, P. A.; Curtis, T. P.; Egerton, T. A.; Kosa, S. A. M.; Tinlin, J. R.; Appl. Catal., B 2003, 41, 371.

16. Palombari, R.; Ranchella, M.; Rol, C.; Sebastiani, G. V.; Sol. Energy Mater. Sol. Cells 2002, 71, 359.

17. Krýsa, J.; Zlámal, M.; Waldner, G.; J. Appl. Electrochem. 2007, 37, 1313.

18. De Nora, V.; British Pat. 1, 231, 280;1,235,570, 1970. 
19. Gusmão, I. C. P.; de Moraes, P. B.; Bidoia, E. D.; Braz. J. Microbiol. 2009, 40, 649.

20. Claro, E. M. T.; Otenio, M. H.; Bidoia, E. D.; Silva, N. M. M. G.; Santos V.; Quim. Nova 2010, 33, 557.

21. Ksibi, M.; Zemzemi, A.; Boukchina, R.; J. Photochem. Photobiol., A 2003, 159, 61.

22. APHA; Standard Methods for the Examination of Water and Wastewater, $17^{\text {th }}$ ed.; American Public Health Association: Washington, 1989.

23. Lathasree, S.; Nageswara Rao, A.; Siva Sankar, B.; Sadasivam, V.; Rengaraj, K.; J. Mol. Catal. A: Chem. 2004, 223, 101.

24. Régis, G.; Bidoia, E. D.; Salusvita 2001, 20, 53.

25. Inazaki, T. H.; Pião, A. C. S.; Bidoia, E. D.; Braz. Arch. Biol. Technol. 2004, 47, 983.

26. Sharf, J. M.; Exame Microbiológico de Alimentos; Polígono: São Paulo, Brasil, 1972.

27. Christensen, P. A.; Egerton, T. A.; Kosa, S. A. M.; Tinlin, J. R.; Scott, K.; J. Appl. Electrochem. 2005, 35, 683.

28. Castañeda, L.; Alonso, J. C.; Ortiz, A.; Andrade, E.; Saniger, J. M.; Bañuelos, J. G.; Mater. Chem. Phys. 2003, 77, 938.
29. Andrade, L. S.; Laurindo, E. A.; Oliveira, R. V.; Rocha-Filho, R. C.; Cass, Q. B.; J. Braz. Chem. Soc. 2006, 17, 369.

30. Tryba, B.; Morawski, A. W.; Inagaki, M.; Toyoda, M.; Appl. Catal., B 2006, 63, 215.

31. Chun, H.; Yizhong, W.; Hongxiao, T.; Chemosphere 2000, 41, 1205.

32. Johnson, S. K; Houk, L. L.; Feng, J.; Houk, R. S.; Johnson, C.; Environ. Sci. Technol. 1999, 33, 2638.

33. Gimeno, O.; Carbajo, M.; Beltrán, F. J.; Rivas, J.; J. Hazard. Mater. 2005, B119, 99.

34. Rajeshwar, K.; Ibanez, J. G.; Swain, G. M.; J. Appl. Electrochem. 1994, 24, 1077.

35. Tiburtius, E. R. L.; Peralta-Zamora, P.; Leal, E. S.; Quim. Nova 2004, 27, 441 .

Submitted: March 30, 2011

Published online: June 28, 2011

FAPESP has sponsored the publication of this article. 